Kok M., H. Massinen, I. Moshnikov, E. Penttilä, S. Tavi \& L. Tuomainen (toim.) 2019. Pidetään kielet elävinä - Keeping languages alive - Piemmö kielet elävinny. AFinLAn vuosikirja 2019. Suomen soveltavan kielitieteen yhdistyksen julkaisuja n:o 77. Jyväskylä. s. 77-100.

Karoliina Inha \& Ari Huhta

Jyväskylän yliopisto

\title{
Kieltenopetus vuosiluokilla 1-3: Miten oppilaat siihen suhtautuvat ja mitä tuloksia sillä saavutetaan puolen vuoden opiskelun aikana?
}

As of January 2020, all Finnish pupils are to start their foreign language studies in the first grade. This study examined the effects of early language teaching by comparing pupils in grades 1, 2 and 3. The pupils had started studying English in August 2017 and had all had roughly the same number of English lessons by the time of the study in early 2018. The study examined pupils' attitudes towards English and studying English as well as how pupils use English in their free time. Pupils also self-assessed their English skills and completed vocabulary and text segmentation tasks. The results show that the pupils had an overall positive attitude towards English and language learning. Analyses of pupils' language skills and extramural use of English revealed statistically significant differences between 1st, 2nd and 3rd graders. Findings and their possible explanations are discussed.

Keywords: ELL, motivation, attitude, extramural activities

Asiasanat: kieltenopetus, varhentaminen, motivaatio, vapaa-aika 


\section{Johdanto}

Vuoden 2019 loppuun voimassa olevan perusopetuksen tuntijaon (Valtioneuvoston asetus 422/2012) mukaisesti A1-kielen opiskelu on aloitettava viimeistään perusopetuksen 3. luokalla. Kieltenopetuksen varhentaminen alkamaan jo 1. tai 2. luokalla on yleistynyt vuodesta 2016 alkaen (Inha 2018), ja valtioneuvoston päätöksen mukaisesti 2020 alusta jokainen oppilas aloittaa kieltenopiskelun viimeistään 1. luokan keväällä (Valtioneuvoston asetus 793/2018). Kevään 2018 tutkimuksessamme selvitimme, mitä 1.-3.-luokkalaiset pitivät englannin kielestä ja sen opiskelusta, miten he käyttivät englantia vapaa-ajallaan sekä minkälaista kielitaitoa he ehtivät hankkia jo puolen vuoden opiskelun aikana. Tutkimus on ensimmäinen osa laajempaa pitkittäistutkimusta varhaisen kieltenopetuksen vaikutuksista vieraan kielen oppimiseen.

\section{Taustaa}

Suomessa ensimmäisen vieraan kielen tai toisen kotimaisen kielen opetus A1-kielenä on ollut mahdollista käynnistää 1. tai 2. luokalla vuodesta 1994 lähtien. Harva opetuksen järjestäjä kuitenkaan tarttui mahdollisuuteen (Vipunen 2019). Vuoden 2012 perusopetuksen tuntijakoasetuksen (Valtioneuvoston asetus 422/2012) ja uusien opetussuunnitelman perusteiden (Opetushallitus 2014) tullessa voimaan syksyllä 2016 varhainen kieltenopetus lisääntyi merkittävästi, kun yksi yläkoulun A1-kielen vuosiviikkotunti siirtyi alakoulun puolelle. Moni opetuksen järjestäjä sijoitti tunnin 2. vuosiluokalle. Vuonna 2015 vain 11 prosenttia 2.-luokkalaisista oli aloittanut A1-kielen opiskelun, mutta vuonna 2016 jo runsas kolmasosa 2.-luokkalaisista osallistui kieltenopetukseen (Vipunen 2019).

Kieltenopetuksen varhentaminen sai tukea myös pääministeri Juha Sipilän hallitusohjelmasta (ks. Opetushallitus 2019a), jonka Uusi peruskoulu -kärkihankkeeseen sisältyi tavoite varhentaa, monipuolistaa ja lisätä kieltenopetusta. Kärkihankkeeseen osallistuneet opetuksen järjestäjät varhensivat yleisimmin A1-englantia alkamaan 1. tai 2. luokalta (Inha 2018).

Euroopan tasolla varhainen kieltenopetus ei ole uusi asia. Se oli esillä vuoden 1997 Euroopan unionin neuvoston päätöslauselmassa (1998), ja se sisältyi komission vuoden 2003 toimintasuunnitelmaan vuosille 2004-2006 (Euroopan komissio 2003). Toimintasuunnitelman tavoitteiden mukaisesti jokaisella kansalaisella kielitaito noudattaisi ' $1+2$ '-sääntöä eli äidinkielen lisäksi opittaisiin kahta vierasta kieltä, joiden opiskelu aloitettaisiin jo nuorella iällä. Komission toimeksiantona Edelenbos, Johnstone ja Kubanek (2006) laativat varhaisesta kieltenopetuksesta laajan raportin, jonka tarkoitus oli tukea varhentamista (ks. myös Euroopan komissio 2011). 
Suuressa osassa Eurooppaa lapset aloittavat ensimmäisen vieraan kielen opiskelun 6-8-vuotiaana, monessa maassa jo ennen viiden vuoden ikää (Euroopan komissio/EACEA/Eurydice 2017). Termillä varhainen tai varhennettu kieltenopetus ei viitatakaan mihinkään yksikäsitteiseen kieltenopetuksen aloitusajankohtaan. Opetuksen varhentaminen on aina riippuvainen siitä kontekstista, missä se esitetään (Skinnari \& Halvari 2018). Omassa tutkimuksessamme varhainen kieltenopetus viittaa vuosiluokkien 1-2 kieltenopetukseen.

Varhaisen kieltenopetuksen tavoitteita on selvitetty useissa hankkeissa. Laajassa metatutkimuksessa Nikolov ja Mihaljević Djigunović (2011) esittävät, että varhentamisella on tavoiteltu yhtä tai useampaa seuraavista tavoitteista: 1) korkeampi kielitaito, 2) korkeampi motivaatio opiskella useita kieliä ja 3) oppilaiden kasvanut tietoisuus eri kielistä ja kulttuureista sekä myönteinen asennoituminen niihin. Yleisiksi opetuksen sisällöiksi tutkijat mainitsevat sekä oppilaan arkeen liittyvän sanaston että oppiainekohtaiset aihepiirit. Opetuksen aihepiirien havaittiin vaihtelevan myös sen mukaan, oliko tavoitteena keskittyä tiettyyn kohdekieleen vai herätellä tietoisuutta useista kielistä (mp.).

Laajassa eurooppalaisessa ELLiE-hankkeessa selvitettiin varhaisen kieltenopetuksen käytäntöjä ja tuloksia, kuten opettajien pätevyysvaatimuksia, täydennyskoulutustarpeita sekä oppijoiden asenteita, motivaatiota ja kuvaa itsestään kielenoppijoina (Enever 2011). Selvityksessä todettiin kieltenopetuksen alkavan Euroopassa viimeistään lasten ollessa 9-vuotiaita. Varhaisvaiheen opetuksen havaittiin painottuvan pääasiassa suullisen kielitaidon kehittämiseen.

Saksasta on raportoitu suulliseen tuottamiseen ja kuullun ymmärtämiseen painottuvasta varhennetusta kieltenopetuksesta, jossa painottuvat leikit, laulut ja pelaaminen (ks. esim. Jäkel ym. 2017; Piske 2017). Engel ja Groot-Wilkenin (2007) tutkimuksessa havaittiin, että vaikka rutiininomaisten suullisten ilmaisujen opettaminen voi johtaa vahvempiin kuullun ja luetun ymmärtämisen taitoihin, tämä ei välttämättä ylläpidä motivaatiota. Opetuksessa tulisi tarjota mahdollisuuksia käyttää kieltä luovasti ja näin tukea lasten vuorovaikutustaitojen kehittymistä (Becker \& Roos 2016). Iso-Britanniassa tehdyssä tutkimuksessa Mitchell ja Myles (2018) painottavat, että varsinaisen kielitaidon kerryttämisen ohessa varhaisen kieltenopetuksen tulisi tukea (kielen)opiskelutaitojen kehittymistä. Näin voitaisiin tukea oppijoiden motivaatiota opiskella kieliä sekä pystyvyyden tunnetta kielen käyttäjinä.

Edellä on jo viitattu Euroopan komission linjauksiin, joilla on pyritty varhentamaan kieltenopetusta. Euroopan neuvosto on puolestaan korostanut kielten ja kielitaidon merkitystä demokratian, yhdenvertaisuuden ja osallisuuden toteutumisessa kuin myös kielitietoisuuden ja kielikasvatuksen roolia kieltenopetuksessa ja koulutuksen kehittämisessä (Mattila 2015). Varhaisessa kieltenopetuksessa Euroopan neuvoston vaikutus painottuu yksilön ja yhteisöjen monikielisen ja monikulttuurisen kompetenssin ymmärtämiseen ja vahvistamiseen (ECML 2019a; ECML 2019b). 
Euroopan neuvoston suositusten (Euroopan neuvosto 2007; ks. myös Euroopan neuvosto 2015) mukaisesti Suomen Perusopetuksen opetussuunnitelman perusteissa 2014 esiintyy merkittävässä roolissa kielikasvatus (Opetushallitus 2014). Yhteiskunnat ovat kielellisesti ja kulttuurisesti yhä moninaisempia, mikä vaatii niin yksilöltä kuin yhteisöltä taitoa kohdata toiseutta, sekä avointa ja myönteistä asennetta muita ihmisiä, kieliä ja kulttuureita kohtaan. Taitoihin lukeutuvat mm. vuorovaikutustaidot, kielelliset ja kulttuuriset taidot ja ymmärrys sekä pyrkimys asettua toisen henkilön asemaan (Mustaparta ym. 2015; ks. myös Mattila 2015), ja nykyisissä perusteissa kielikasvatus on johdantona jokaiseen kieliaineeseen. Kieltenopetuksen tavoitteena onkin paitsi kielelliset ja kielenopiskeluun liittyvät tavoitteet myös kielitietoisuuteen sekä moninaisuutta arvostavaan kieli- ja kulttuuri-identiteettiin kasvaminen.

Toukokuussa 2019 julkaistiin vuosiluokkien 1-2 A1-kielen opetussuunnitelman perusteet. Oppiaineen erityistehtäväksi vuosiluokilla 1-2 mainitaan mm. myönteisen asenteen herättäminen kieltenoppimiseen, omiin kykyihin luottamisen vahvistaminen sekä kielen käyttöön rohkaiseminen (Opetushallitus 2019b). Opetuksen tavoitteet noudattavat eurooppalaista näkökulmaa: opetuksen tulee ohjata oppilaan kielitietoisuuden ja kulttuurisen osaamisen kehittymistä, kielenopiskelutaitojen oppimista sekä erityisesti suullisen kielitaidon ja vuorovaikutustaitojen kehittymistä kohdekielellä. Perusteissa asetetuissa työtapojen ja oppimisympäristöjen tavoitteissa korostuvat toiminnallisuus, monipuoliset vuorovaikutustilanteet sekä luontaista uteliaisuutta ja kokeilunhalua tukevat oppimisympäristöt. Sisältöjen valinnoissa otetaan huomioon lasten mielenkiinnon kohteista sekä arjesta nousevat aiheet. Uudet perusteet noudattavatkin eurooppalaisia kielikasvatuksen suosituksia unohtamatta kielenkäyttötaidon kehittämistä jo varhaisessa vaiheessa.

\section{Varhaisen kieltenopetuksen vaikutukset tutkimuk- sen näkökulmasta}

\subsection{Vaikutukset kielitaitoon}

Hyvän kielitaidon saavuttamista vieraassa tai toisessa kielessä on pidetty mahdollisena silloin, kun lapsi saa riittävästi kielisyötettä (input) ja mahdollisuuksia käyttää kieltä arjessaan. Tutkimustuloksia maahanmuuttajataustaisten lasten toisen kielen oppimisesta sekä nk. kielellisten herkkyyskausien ja luonnollisen kielenoppimisen hyödyistä on yleistetty formaalin kieltenopetuksen puolelle (ks. DeKeyser 2013). Muutoksia opetusjärjestelyissä on suunniteltu siihen perustuen, että kielenoppimisen aloitusikä olisi merkitsevä tekijä saavutettavan kielitaidon kannalta. Tällöin kiel- 
tenopetus on saatettu päättää aloittaa aiempaa käytäntöä varhaisemmin lisäämättä kuitenkaan kieltenopetuksen kokonaistuntimäärää (mp.).

Koulussa oppilas kuitenkin altistuu opiskeltavalle kielelle vain murto-osan siitä, mitä maahanmuuttajataustainen lapsi altistuu toisen kielen oppijana. DeKeyser (2013) huomauttaakin, että vaikka tutkimuksella pystyttäisiinkin osoittamaan varhaisen kielenoppimisen hyödyllisyys, eivät tulokset välttämättä ole relevantteja koulutuksen suunnittelulle. Varhaisen kielenoppimisen hyötyjä tavoitellaan myös Suomen A1-kielen opetuksen varhentamispäätöksellä. Suomessa A1-oppimäärää kuitenkin kasvatettiin kahdella vuosiviikkotunnilla (Opetus- ja kulttuuriministeriö 2018: 11).

Muñozin (2008) mukaan tutkimukset varhaisen kieltenopetuksen vaikutuksista kielitaitoon eivät aukottomasti osoita, että luonnollisen kielenoppimisen hyödyt olisivat mahdollisia myös formaalissa kieltenopetuksessa. Varhaisen aloitusiän vaikutuksia kielitaitoon on tutkittu laajasti mm. Espanjassa Barcelona Age Factor (BAF) -projektissa (Muñoz 2006). Tulokset osoittivat, että myöhemmin kieltenopiskelun aloittaneet oppilaat suoriutuivat varhemmin opiskelunsa aloittaneita oppilaita paremmin kielitaitoa mittaavissa tehtävissä. Saksassa Jäkelin ym. (2017) tutkimus osoitti, että erot kielitaidossa eri vuosiluokilla kieltenopiskelun aloittaneilla oppilailla tasaantuvat 7. luokkaan mennessä. Tutkijoiden mukaan opetusta ja kielisyötettä tulisi tarjota riittävästi, jos tavoitteena on kielitaidon korottaminen (Jäkel ym. 2017). Tutkimusta on kuitenkin kritisoitu siitä, että se keskittyi reseptiivisiin taitoihin ja kieliopin hallintaan. Varhaisella kieltenopetuksella tavoitellaan kuitenkin myös kielikasvatukselle ominaisia tavoitteita, kuten monikielisyyteen kasvamista ja interkulttuurisia taitoja (Böttger \& Schlüter 2019; ks. myös Opetushallitus 2014, 2019).

Iso-Britanniassa on selvitetty, miten aloitusikä vaikuttaa kielitaidon lisäksi kieltenopiskelutaitoihin ja asenteisiin (Tellier \& Myles 2018). Tulosten mukaan aloitusiällä ei ollut merkittävää vaikutusta sanastonhallinnan kehittymiseen, joskin sanasto kehittyi nopeimmin ja oli laajinta vanhemmilla oppilailla. Lisäksi vanhemmilla oppilailla oli vahvempi kieliopin hallinta ja he käyttivät monipuolisemmin kielenopiskelustrategioita. Toisaalta nuoremmat oppilaat olivat innokkaampia oppimaan kieliä (Myles \& Mitchell 2012; Myles 2017).

García Mayon (2003) tutkimuksessa selvitettiin aloitusiän vaikutuksia arvioimalla oppilaiden kielitaitoa, metalingvististä tietoisuutta ja tuotosten kieliopillista hyväksyttävyyttä mittaavilla tehtävillä. Tulokset osoittivat, että varhaisempi aloitus ei johtanut merkitsevästi parempiin tuloksiin. Tutkija esittää, että varhaiselta kieltenopetukselta ei voi olettaa tuloksellisuutta ilman laadukasta opetusta ja lisäystä tuntimäärään. Hän lisää, että kieltä tulisi käyttää sekä opetuksessa että luokkahuonevuorovaikutuksessa ja toteaa, että opetuksen tuloksellisuuteen voisi vaikuttaa sisällyttämällä siihen piirteitä kaksikielisestä opetuksesta sekä vaikuttamalla oppilaiden motivaatioon opiskella kieltä (mp.). 
Myöhemmällä iällä aloittaneiden oppilaiden parempia tuloksia on selitetty mm. kehittyneemmällä kognitiivisella kyvykkyydellä (García Mayo 2003). Lisäksi varhainen kieltenopetus voi olla hyvin erilaista kuin vanhemmille oppilaille annettu opetus. Lasten kanssa oppimisesta on pyritty tekemään mahdollisimman 'luonnollista' ja puhuttuun ja ymmärrettyyn kieleen keskittyvää, kun taas vanhempien oppilaiden opetus voi olla oppikirjapainotteista ja kirjoitettuun kieleen perustuvaa. Täten myös erilainen lähestymistapa kieltenopetukseen voi selittää, miksi vanhemmat oppilaat vaikuttavat pärjäävän paremmin kielitehtävissä. (Muñoz 2006; Cenoz 2009).

Tutkimuskenttä on hiljalleen siirtynyt pois ns. aloitusikäkeskeisyydestä kohti muita mahdollisia tekijöitä. Näihin lukeutuvat mm. kielisyötteen määrä, laadukkaan opetuksen käytännöt sekä opettajan pätevyysvaatimukset (mm. Enever 2011; Dahl \& Vulchanova 2014; Graham ym. 2017). Esimerkiksi Mihaljević Djigunović (2009) tutki kroatialaisissa kouluissa, miten oppimiskonteksti vaikuttaa kahden eri opetusryhmän suhtautumiseen englannin kieleen. Tulokset osoittivat, että toiminnallinen ja useana oppituntina viikossa annettava opetus voi johtaa oppilaiden myönteisempiin asenteisiin ja pystyvyyden tunteisiin kieli- ja kieltenopiskelutaidoissa (mp.). Dahl ja Vulchanova (2014) tutkivat Norjassa, miten kielisyötteen määrä ja opetustyyli vaikuttavat englannin kielen oppimiseen. Tulosten mukaan yksi oppitunti viikossa ei vaikuttanut merkittävästi oppilaiden reseptiiviseen sanastoon. Lisäksi tutkijat toteavat, että lasten altistuminen englannille koulun ulkopuolella on niin vähäistä, ettei sillä ole merkittävää vaikutusta oppimiseen. Sen sijaan kaksikieliseen opetukseen osallistuvilla oppilailla, jotka saivat kielisyötettä myös englannin tuntien ulkopuolella, reseptiivinen sanasto kehittyi merkitsevästi tutkimuksen aikana (vrt. García Mayo 2003).

\subsection{Motivaatio ja kohdekielen käyttö vapaa-ajalla}

Varhaisella kieltenopetuksella on pyritty myös vaikuttamaan oppilaiden motivaatioon opiskella kieliä. Useat tutkimukset osoittavat, että nuoret lapset ovat innokkaita kielenoppijoita (Cenoz 2003; Engel \& Groot-Wilken 2007; Enever 2011; Myles 2017). Brumenin (2011) Sloveniassa tehdyn tutkimuksen mukaan lapset nauttivat kieltenoppimisesta ja leikinomaisista opetustavoista sekä ovat varmoja omasta kielitaidostaan. Toisaalta on myös havaittu, että motivaatio voi herkästi laskea iän myötä (Mihaljević Djigunović 2009), minkä takia myönteisen suhtautumisen ylläpitämistä tulisi tukea opetuksessa (Myles 2017).

Pfenninger ja Singleton (2016a, 2016b) vertasivat Sveitsissä eri vuosiluokilla englannin opiskelun aloittaneiden oppilaiden motivaatiota sekä suhtautumista opiskeluun ja opiskelun aloitusajankohtaan. Tulokset osoittivat, että vanhemmat oppilaat olivat motivoituneita ja tyytyväisiä myöhempään opiskelun aloitusajankohtaan, kun taas nuoremmat oppilaat helposti turhautuivat ensimmäisien opiske- 
luvuosien aikana kertyvän kielitaidon vähäisyyteen ja opetuksen hitaaseen etenemistahtiin (mp.).

Tarkasteltaessa varhaista kieltenopetusta, kohdekielen käyttöä vapaa-ajalla sekä sen mahdollisia vaikutuksia oppimiseen on todettu, että alle kouluikäisten kohdekielen käyttö on vielä hyvin vähäistä (Unsworth ym. 2014; vrt. Dahl \& Vulchanova 2014). Sundqvist ja Sylvén (2014) tutkivat Ruotsissa, missä määrin ja mihin tarkoitukseen 4.-luokkalaiset käyttävät englannin kieltä vapaa-ajallaan. Tulokset osoittivat, että oppilaat katsovat paljon englanninkielisiä tv-ohjelmia, kuuntelevat englanninkielistä musiikkia ja pelaavat tietokonepelejä, joissa pelaajat käyttävät englantia keskenään. Pojat käyttivät enemmän englantia vapaa-ajallaan kuin tytöt, mikä näkyi erityisesti tietokonepelien pelaamisessa ja elokuvien katselussa. Tytöt sen sijaan selasivat enemmän englanninkielistä verkkomateriaalia. Sekä suullista että kirjallista kielenkäyttöä vaativien pelien pelaaminen korreloi vahvan sanastonhallinnan kanssa (mp.).

Sundqvistin ja Sylvénin (2014) mukaan paljon englannin kieltä vapaa-ajallaan käyttäneet oppilaat olivat epävarmempia kielitaidostaan. Tutkijat toteavatkin tuloksen mahdollisesti johtuvan siitä, että runsas kielenkäyttö vapaa-ajalla voi tehdä näkyvämmäksi oman kielitaidon puutteet. Runsaasti englantia käyttävät lapset eivät myöskään välttämättä koe oppitunneilla hankitun kielitaidon soveltuvan suoraan oikeaan kielenkäyttötilanteeseen.

Hannibal Jensen (2017) tutki, miten tanskalaiset 8- ja 10-vuotiaat käyttävät englantia vapaa-ajallaan. Tulokset vastasivat Sundqvistin ja Sylvénin (2014) havaintoja. Oppilaat kuulivat ja käyttivät englantia paljon tv-ohjelmissa, elokuvissa, musiikissa ja peleissä. Vanhempana opiskelun aloittaneet oppilaat suoriutuivat nuorempia paremmin kielitaitoa mittaavissa tehtävissä. Tutkijan mukaan tämä voisi johtua siitä, että vanhemmat oppilaat ovat oppineet englantia vapaa-ajan harrastustensa kautta jo ennen kieltenopiskelun aloittamista koulussa. Vanhempien oppilaiden ryhmässä pojat pärjäsivät paremmin kuin tytöt, minkä arveltiin johtuvan siitä, että pojat harrastavat kieltenoppimista tehostavia harrastuksia, kuten pelaamista, tyttöjä enemmän. Tutkijan mukaan poikien runsas englannin kielen käyttö vapaa-ajalla voi toimia ehkäisevänä tekijänä sille, etteivät erot tyttöjen ja poikien oppimistuloksissa eriydy yhä suuremmiksi. (Hannibal Jensen 2017; vrt. Engel \& Groot-Wilken 2007).

Muñoz, Cadierno ja Casas (2018) tutkivat tanskalaisia ja espanjalaisia 7- ja 9-vuotiaita englannin kielen oppijoita. He selvittivät yhteyttä englannin sanastonhallinnan, äidinkielen ja englannin kielellisen etäisyyden, opetusmäärän, sukupuolen sekä kielen vapaa-ajankäytön välillä. Tulokset osoittivat poikien vahvemman sanastonhallinnan. Toisaalta tulokset eivät osoittaneet yhteyttä tietokonepelien pelaamisen ja vahvan sanastonhallinnan välillä. Tutkijat ehdottavat, että hyvin nuorilla oppijoilla ei vielä ole riittävää kielitaitoa, jotta he hyötyisivät vapaa-ajalla kuullusta ja nähdystä kielestä. Sen sijaan äidinkielen ja opiskeltavan kielen lingvistinen lähei- 
syys näyttäytyy porttina tehokkaampaan kieltenoppimiseen (Muñoz ym. 2018; vrt. Unsworth ym. 2014.)

Edellisten kymmenen vuoden aikana varhaisesta kieltenopetuksesta on tehty yhä enemmän meta- ja pitkittäistutkimusta (mm. Nikolov \& Mihaljević Djigunović 2011; Enever 2011; Wilden ym. 2017) sekä selvityksiä poliittisen päätöksenteon tueksi (mm. Engel \& Groot-Wilken 2007; British Council \& NILE 2017). Tämä tutkimus on esimerkki jälkimmäisestä, ja se tehtiin yhteistyössä Opetushallituksen kanssa selvittämään varhaisen kieltenopetuksen vaikutuksia Suomessa (ks. Huhta \& Leontjev 2019). Tutkimus kohdentui vuosiluokkien 1-3 oppilaisiin, oppilaiden huoltajiin sekä varhennettua kieltenopetusta antaviin opettajiin. Tässä artikkelissa keskitymme oppilaita koskevan tutkimuksen tuloksiin. Artikkelin laadinnassa on hyödynnetty tutkimushankkeen loppuraporttia (Huhta \& Leontjev 2019), jossa on esitetty samat tulokset ja kuvaukset aineistonkeruumenetelmistä tilastollisia vertailuja lukuun ottamatta. Tässä artikkelissa tuloksia kuitenkin kuvataan tarkemmin ja niiden merkitystä pohditaan myös aiemman tutkimuksen valossa.

\section{$4 \quad$ Tutkimus}

\subsection{Tutkimusasetelma}

Keväällä 2018 tehdyssä tutkimuksessamme selvitimme, mitä syksyllä 2017 englannin opiskelun aloittaneet 1.-3.-luokkalaiset pitivät englannin kielestä ja sen opiskelusta sekä miten oppilaiden kielitaito oli oppilaiden omasta mielestä kehittynyt puolen vuoden aikana. Lisäksi kartoitimme, miten oppilaat käyttivät englantia vapaa-ajallaan ja minkälaista kielitaitoa he olivat saavuttaneet jo puolen vuoden opiskelun jälkeen.

Tehty aineistonkeruu tarjoaa kattavan pohjan myös pitkittäistutkimukselle. Selvitys antaa tietoa eri vuosiluokilla kieltenopiskelun aloittaneiden englannin kielen osaamisesta opintojen alkuvaiheessa ja siten toimii hyvin lähtötilanteen kartoituksena. Jatkossa voimme seurata samoja oppilaita sekä $\mathrm{mm}$. heidän kielitaitonsa ja opiskelumotivaationsa kehittymistä. Pitkittäistutkimuksella voimme päästä syvemmin kiinni siihen, miten varhainen kieltenopetus vaikuttaa vieraan kielen oppimiseen, sekä tutkia mahdollisia yhteyksiä kielitaidon, motivaation ja vapaa-ajan kielenkäytön välillä.

\subsection{Aineistonkeruu}

Tutkimukseen osallistui 149 ensiluokkalaista, 309 toisluokkalaista sekä 291 kolmasluokkalaista 23 suomenkielistä opetusta tarjoavasta koulusta ympäri Suomea. Noin 
$90 \%$ tutkimukseen osallistuneista oppilaista puhui suomea kotikielenään. Valtaosa oppilaista opiskeli kouluissa, joissa oli käynnissä hallituksen Uusi peruskoulu -kärkihankkeen rahoittama kieltenopetuksen varhentamisen hanke, joka osaltaan velvoitti kouluja osallistumaan tutkimukseen. Kouluja lähestyttiin rehtoreiden ja opettajien kautta. Vanhempien ja oppilaiden luvat tutkimukseen osallistumisesta hankittiin koulujen kautta. Noin puolet kustakin tutkimukseen osallistuneen luokan oppilaista osallistui tutkimukseen.

Aineistonkeruussa käytettiin taustakyselylomaketta ja kahta erityyppistä kielitehtävää. Tehtävät suoritettiin keväällä 2018 yhden tai kahden oppitunnin aikana. Kielitehtävät keskittyivät sanastoon ja kielen rakenteelliseen hahmottamiseen, sillä aikaisempi tutkimus on osoittanut niiden olevan hyviä englannin oppimisen ennustajia suomalaisilla oppilailla (Alderson ym. 2015; Alderson ym. 2016). Esimerkiksi Alderson ym. (2016: 861) havaitsivat vieraan kielen sanaston laajuuden ja segmentoinnin tarkkuuden erottelevan parhaimmat ja heikoimmat neljäsluokkalaiset vieraalla kielellä lukevat erittäin selvästi toisistaan.

Moni 1.-luokkalainen alkaa harjoitella äidinkielen luku- ja kirjoitustaitoa vasta kouluun tullessaan, minkä vuoksi päätimme heidän kohdallaan teettää tutkimuksen yksilöhaastatteluina tutkimusavustajan kanssa. Avustaja selitti, mistä kussakin tehtävässä oli kyse, ja tarvittaessa kannusti ja tuki oppilasta tehtävän tuntuessa hänestä vaikealta. Tehtävä jätettiin kesken, jos oppilaan taidot eivät vielä riittäneet sen tekemiseen. 2.- ja 3.-luokkalaiset tekivät tehtävät kirjallisesti luokassa tutkimusavustajan ja/tai opettajan johdolla. Oppilaiden sallittiin jättäytyä pois tutkimuksesta kesken mittauksen heidän niin halutessaan.

Edellä mainittujen tehtävien lisäksi 1.-luokkalaisten kanssa käytiin lyhyt englanninkielinen keskustelu, jossa oppilaat saivat kertoa esimerkiksi nimensä ja lemmikistään englanniksi, tarvittaessa myös suomeksi. Tutkimuksessa mitattiin suullista kielitaitoa, sillä varhennetun kieltenopetuksen kokeiluissa opetus on painottunut juuri sen kehittämiseen (Inha 2018). Suullisen kielitaidon arvioinnin tuloksia ei käsitellä tässä artikkelissa (ks. Huhta \& Leontjev 2019).

\subsection{Tutkimusvälineet}

Tutkimusvälineiden valinta perustui tasapainottelulle tutkimuksen laajuuden, laadun ja käytännön rajoitusten välillä. Taustakyselylomakkeella selvitettiin oppilaiden asenteita englannin kieltä ja englannin opiskelua kohtaan. Ensiksi oppilaita pyydettiin kertomaan, mitä he pitävät englannin opiskelusta, mikä siinä on mukavinta ja mikä vaikeaa. Sen jälkeen he merkitsivät viisiportaisella Likert-asteikolla parhaiten sopivat vastaukset kysymyksiin Miten mukavaa sinusta on opiskella englantia koulussa ja Mitä pidät englannin kielestä. Vastaus valittiin jatkumolta en pidä siitä ollenkaan - pidän siitä tosi paljon. 
Taustakyselylomakkeen seuraavassa osiossa oppilaita pyydettiin tekemään itsearviointi oppimisestaan. Heitä pyydettiin arvioimaan, miten hyvin he olivat mielestään osanneet englantia ennen opintojen alkamista syksyllä 2017 sekä miten hyvin he tutkimuksen ajankohtana sitä mielestään osasivat. Itsearviointi tehtiin neliportaisella asteikolla, ja se jakautui puhumisen ja ymmärtämisen osaamisen arviointiin. Vastausvaihtoehdot olivat seuraavat: en yhtään, osasin sanoa/ymmärsin muutaman sanan, osasin esimerkiksi kertoa muutaman asian/ymmärsin muutaman lauseen, osasin puhua/ymmärsin jo aika hyvin.

Taustakyselylomakkeen viimeisessä osiossa oppilaille esitettiin erilaisia vapaa-ajan harrastuksia (mm. tv:n katselu, tietokonepelien pelaaminen) ja heitä pyydettiin merkitsemään, missä kaikissa he käyttävät englantia ja miten usein. Oppilaat saivat täydentää vastaustaan avokysymyksessä.

Kielitehtäviä oli sekä suomenkielisiä että englanninkielisiä. Oppilaiden englannin sanaston laajuutta mitattiin käyttämällä standardoitua, suomalaiseen kontekstiin sovitettua sanastopakettia. Englannin ja suomen kielen rakenteellista hahmottamista mitattiin segmentointitehtävien avulla. Näissä oppilaat merkitsivät sanarajat lauseisiin, jotka oli kirjoitettu yhteen ilman sanavälejä, välimerkkejä tai isoja alkukirjaimia.

Kielitehtävät ovat peräisin Jyväskylän yliopiston vuosina 2010-2013 tekemästä DIALUKI-tutkimusprojektista (Jyväskylän yliopisto 2014; Alderson ym. 2015). Tutkimuksessa selvitettiin tehtävien soveltuvuutta ennustaa oppilaiden englannin luku- ja kirjoitustaitoa. Sanavaraston laajuutta ja kirjoitetun kielen hahmottamista testaavat tehtävät osoittautuivat toimiviksi ja ennustivat sekä samanaikaista että myöhempää englannin osaamista (ks. Alderson ym. 2015; Alderson ym. 2016). Koska tässä raportoitavaa tutkimusta on tarkoitus jatkaa tulevaisuudessa, oppilaiden lähtötason arviointiin haluttiin valita erityisesti tällaisia ennustuskyvyltään hyviksi osoittautuneita tehtäviä.

Englannin sanastotehtävä perustuu 2000-luvun alussa kehitettyyn kansainväliseen testiin, The Vocabulary Levels Test (Schmitt ym. 2001). Tehtävät rakentuvat englannin sanojen esiintymistiheydelle, eli kukin tehtävä koostuu sanoista, jotka esiintyvät tietyllä tiheystasolla. DIALUKI-hankkeessa kehitettiin edellä mainitusta testistä kaksi versiota, joita käytimme myös tässä tutkimuksessa. Ensimmäinen rakentuu otokselle 500 yleisimmästä englannin sanasta (pois lukien funktiosanat) ja toinen sanoille, jotka esiintyvät taajuusvälillä 500-1000. Yhdessä tehtävässä oli 60 englanninkielistä sanaa jaettuna kuuden sanan ryhmiin. Kussakin ryhmässä oli kolme suomenkielistä sanaa, jotka olivat käännösvastineita kolmesta samassa ryhmässä esitetystä englanninkielisestä sanasta. Oppilaan tehtävä oli merkitä, mitkä sanat vastasivat toisiaan. Esimerkiksi yhdessä osiossa olivat sanat vesi, mies ja ihmiset ja niille vastineet man, number, people, time, water ja year.

Segmentointitehtävät on kehitetty Niilo Mäki Instituutissa (NMI) ja sitä käytetään osana lukemisvaikeuksien seulontaan kehitettyä tehtävistöä (Holopainen ym. 
2004). Tässä tutkimuksessa käytimme DIALUKI-hankkeessa alakouluun kehitettyjä sovelluksia, joissa NMI:n versiossa käytetyt erilliset sanaketjut (esimerkiksi kilttitörmätätakkietana) korvattiin kokonaisilla, toisiinsa liittyvillä lauseilla. Tehtävässä mitattiin suoritusaikaa ja suorituksen tarkkuutta eli virheiden määrää. Virheiksi laskettiin merkitsemättä jätetyt sanarajat sekä väärissä paikoissa olevat sanarajat. Sanaketjutehtävässä ja erityisesti sen vieraskielisessä versiossa virheiden määrän on todettu ennustavan myöhempää vieraan kielen osaamista (ks. esim. Alderson ym. 2016).

\subsection{Tilastolliset menetelmät}

Oppilaiden vastaukset analysoitiin tilastollisesti käyttäen sekä kuvailevia menetelmiä että testaamalla tilastollisia merkitsevyyksiä monimuuttujaisella varianssianalyysillä (Manova). Vuosiluokkien eroja tarkasteltiin parittaisilla vertailuilla, joissa käytettiin Games-Howell-menetelmää. Keskeisimpien analyysien tulokset tarkistettiin vielä Kruskal-Wallisin ei-parametrisilla analyyseillä, sillä muuttujien jakaumat eivät aina täysin täyttäneet Manovan vaatimuksia.

\section{Tulokset}

\subsection{Itsearviointi}

Ensimmäinen kysymys koski oppilaiden taitoa puhua ja ymmärtää englantia lukuvuoden alkaessa. Noin viidesosa 1.-luokkalaisista ja vain muutama prosentti 2.- ja 3.-luokkalaisista arvioi, ettei osannut lainkaan puhua englantia aloittaessaan kyseisen vuosiluokan. Sen sijaan noin viidesosa 2.- ja 3.-luokkalaisista arvioi osanneensa puhua englantia jo melko hyvin. Tulokset oppilaiden arvioista englannin ymmärtämistaidoistaan olivat hyvin samanlaiset.

Melkein 75 prosenttia 3.-luokkalaisista arvioi tutkimuksen ajankohtana osaavansa puhua englantia jo melko hyvin. Ensimmäisen ja toisen luokan oppilaista vain runsas kolmasosa arvioi näin. Ymmärtämisessä tulokset olivat hyvin samanlaisia. Vain muutama oppilas ilmoitti, ettei lainkaan puhunut tai ymmärtänyt englantia puolen vuoden opiskelun jälkeen.

Verrattaessa 1.-luokkalaisten ja 2.- ja 3.-luokkalaisten itsearviointeja keskenään oli jälkimmäisellä ryhmällä omasta mielestään paljon vahvempi osaaminen englannin kielessä sekä lukuvuoden alussa että puolen vuoden opiskelun jälkeen. Erityisesti kolmasluokkalaisten näkemys osaamisen kertymisestä oli hyvin myönteinen. Niiden 3.-luokkalaisten, jotka puhuivat ja ymmärsivät englantia mielestään jo aika hyvin, määrä kasvoi noin 50 prosenttiyksiköllä lukuvuoden alusta. 
Taulukko 1 esittää oppilaiden vastausten keskiarvot ja hajonnat vuosiluokittain asteikolla 0-3 (en osannut/osaa mitään - osasin/osaan jo aika hyvin). Taulukossa on myös tilastollisen analyysin tulokset eroista itsearvioinneissa vuosiluokittain eriteltyinä (F-arvot ja efektikoot). Itsearviointien eroja tarkasteltiin ensin monimuuttujaisella varianssianalyysillä Manovalla. Tulokset osoittivat itsearviointien eroavan tilastollisesti merkitsevästi riippuen vuosiluokasta (Wilksin lambda = ,763; F = 24,93; $p<, 001)$, minkä johdosta oli perusteltua tutkia yksittäisiä itsearviointikysymyksiä tarkemmilla analyyseillä.

TAULUKKO 1. Oppilaiden englannin puhumisen ja ymmärtämisen itsearviointi (vastausvaihtoehdot välillä (0-3). Itsearviointien tilastollisen vertailun tulokset vuosiluokittain. S2017 viittaa oppilaiden arvioon omasta osaamisestaan kouluvuoden alussa ja K2018 arvioon tutkimusajankohtana. Molemmat arviot tehtiin keväällä 2018. Ka = keskiarvo.

\begin{tabular}{|c|c|c|c|c|c|c|c|c|c|}
\hline \multirow[t]{2}{*}{$\begin{array}{l}\text { Itsearviointi- } \\
\text { kysymys }\end{array}$} & \multicolumn{2}{|c|}{$\begin{array}{l}\text { 1. luokka } \\
\mathrm{N}=145\end{array}$} & \multicolumn{2}{|c|}{$\begin{array}{l}\text { 2. luokka } \\
\mathrm{N}=304\end{array}$} & \multicolumn{2}{|c|}{$\begin{array}{l}\text { 3. luokka } \\
\mathrm{N}=254\end{array}$} & \multirow[t]{2}{*}{$F$} & \multirow[t]{2}{*}{$\begin{array}{l}\text { Tilast. } \\
\text { merk. }\end{array}$} & \multirow[t]{2}{*}{$\begin{array}{l}\text { Efekti- } \\
\text { koko }\end{array}$} \\
\hline & ka. & keskihaj. & ka. & keskihaj. & ka. & keskihaj. & & & \\
\hline $\begin{array}{l}\text { puhuminen } \\
\text { S2017 }\end{array}$ & 1,00 & ,766 & 1,42 & 885 & 1,77 & ,823 & 38,73 & $<, 001$ & , 101 \\
\hline $\begin{array}{l}\text { puhuminen } \\
\text { K2018 }\end{array}$ & 1,85 & ,908 & 2,13 & 782 & 2,70 & ,526 & 71,24 & $<, 001$ & ,171 \\
\hline $\begin{array}{l}\text { ymmärtäminen } \\
\text { S2017 }\end{array}$ & 0,90 & 817 & 1,30 & 899 & 1,69 & ,863 & 39,51 & $<, 001$ & , 102 \\
\hline $\begin{array}{l}\text { ymmärtäminen } \\
\text { K2018 }\end{array}$ & 1,86 & 905 & 2,06 & 849 & 2,71 & ,514 & 73,81 & $<, 001$ & , 176 \\
\hline
\end{tabular}

Kuten taulukko 1 esittää, olivat erot vuosiluokkien välillä kaikissa itsearviointikysymyksissä tilastollisesti merkitseviä ( $p<, 001$ ). Erot olivat selvimpiä (suurimmat F-arvot ja efektikoot) itsearvioinneissa, jotka koskivat tutkimusajankohtaa eli oppilaiden arvioita osaamisestaan noin puoli vuotta englannin opintojen alkamisen jälkeen. Efektikoot (partial eta squared -arvot) kertovat, että vuosiluokka selittää noin 10 prosenttia vaihtelusta oppilaiden opintojen alkua koskevissa itsearvioinneissa ja noin 17 prosenttia itsearvioinneista, jotka koskivat tutkimusajankohtaa.

Tarkemmat parittaiset analyysit tehtiin Games-Howell-menetelmällä, joka sopii tilanteeseen, jossa ryhmien (tässä vuosiluokkien) vastausten varianssit eroavat toisistaan. Tulokset osoittivat, että kaikkien vuosiluokkien itsearvioinnit erosivat merkitsevästi toisistaan. Ainut poikkeus oli 1.- ja 2.-luokkalaisten itsearvio tutkimuksen aikaisesta englannin ymmärtämisestä: 1.-luokkalaisten keskiarvo 1,86 ei eronnut merkitsevästi 2.-luokkalaisten keskiarvosta 2,06, vaikka p-arvo 0,72 olikin lähellä raja-arvoa 0,5 . Koska muuttujien jakaumat olivat vinoja eivätkä täten noudattaneet 
normaalijakaumaa, tarkistimme tulokset vielä Kruskal-Wallisin ei-parametrisellä testillä. Tulokset osoittivat eri vuosiluokkien oppilaiden vastausten eroavan merkitsevästi $(p<, 001)$ kaikissa itsearviointikysymyksissä.

\subsection{Suhtautuminen englannin kieleen ja englannin opiskeluun}

Valtaosa oppilaista kertoi pitävänsä sekä englannin kielestä että sen opiskelusta. Yli 80 prosenttia kaikkien vuosiluokkien oppilaista kertoi pitävänsä englannin kielestä jonkin verran tai todella paljon. Kysymykseen englannin opiskelusta pitämisestä oppilaat vastasivat pääsääntöisesti myönteisesti. Noin 80 prosenttia oppilaista valitsi jommankumman myönteisistä vastausvaihtoehdoista. Alle 4 prosenttia 1.-3.-luokkalaisista vastasi kysymyksiin en pidä siitä ollenkaan tai en pidä siitä kovin paljon. Erittäin myönteiset vastaukset yleistyivät vuosiluokan mukaan ja olivat tavallisimpia 3.-luokkalaisilla.

Taulukko 2 esittää englannin kieltä ja sen opiskelua koskevien kysymysten keskiarvot ja -hajonnat sekä vuosiluokittain tehdyn vertailun tulokset. Analyysejä varten vastaukset koodattiin asteikolle 0-4 (en pidä siitä ollenkaan - pidän siitä erittäin paljon). Manova-analyysi osoitti, että oppilaiden vuosiluokka vaikutti vastauksiin vain vähän, mutta silti tilastollisesti merkitsevästi (Wilksin Lambda $=, 985 ; \mathrm{F}=$ 2,576; $p=, 032$; efektikoko = ,007).

Tarkemmat analyysit osoittavat, että merkitsevä ero vuosiluokkien välillä koskee englannin kielestä pitämistä, mikä kasvoi asteittain vuosiluokalta toiselle. Erityisesti 3.-luokkalaiset pitivät kielestä enemmän kuin nuoremmat oppilaat. Efektikoko on kuitenkin pieni ja osoittaa, että vain 1,4 prosenttia vastausten vaihtelusta selittyy oppilaan vuosiluokalla (taulukko 2). Tässäkin ei-parametrinen Kruskall-Wallisin testi osoittautui tilastollisesti merkitseväksi $(p=, 001)$ englannin kielestä pitämisen kohdalla.

TAULUKKO 2. Oppilaiden suhtautuminen englannin kieleen ja englannin opiskeluun (vastausvaihtoehdot välillä 0-4). Ka = keskiarvo.

\begin{tabular}{|c|c|c|c|c|c|c|c|c|c|}
\hline \multirow[t]{2}{*}{ Kysymys } & \multicolumn{2}{|c|}{$\begin{array}{l}\text { 1. luokka } \\
\mathrm{N}=144\end{array}$} & \multicolumn{2}{|c|}{$\begin{array}{l}\text { 2. luokka } \\
\mathrm{N}=304\end{array}$} & \multicolumn{2}{|c|}{$\begin{array}{l}\text { 3. luokka } \\
\mathrm{N}=257\end{array}$} & \multirow[t]{2}{*}{$\mathrm{F}$} & \multirow[t]{2}{*}{$\begin{array}{l}\text { Tilast. } \\
\text { merk. }\end{array}$} & \multirow[t]{2}{*}{$\begin{array}{l}\text { Efekti- } \\
\text { koko }\end{array}$} \\
\hline & ka. & keskih. & ka. & keskih. & ka. & keskih. & & & \\
\hline $\begin{array}{l}\text { kielestä } \\
\text { pitäminen }\end{array}$ & 3,01 & 714 & 3,09 & ,869 & 3,25 & ,830 & 4,83 & ,008 & ,014 \\
\hline $\begin{array}{l}\text { opiskelusta } \\
\text { pitäminen }\end{array}$ & 3,10 & ,831 & 3,12 & 946 & 3,19 & ,813 & 0,66 & ,518 & ,002 \\
\hline
\end{tabular}




\subsection{Englannin kielen käyttö vapaa-ajalla}

Kyselylomakkeessa oppilailta kysyttiin lopuksi, miten he käyttävät englantia vapaa-ajallaan. Oppilaille esitettiin kuusi eri tilannetta ja heitä pyydettiin merkitsemään kunkin tilanteen kohdalle, kuinka usein ne esiintyvät heidän arjessaan jatkumolla harvemmin tai en koskaan - joka päivä tai melkein joka päivä. Tilanteet olivat seuraavat: 1) puhun englantia jonkun kanssa, 2) kuuntelen lauluja englannin kielellä, 3) katselen englanninkielisiä ohjelmia TV:stä, 4) pelaan englanninkielisiä tietokonepelejä, 4) luen jotain englanniksi, 5) kirjoitan jotain englanniksi, 6) teen jotain muuta englanniksi.

1.-luokkalaiset käyttivät englantia pääasiassa lauluja kuunnellessaan, televisiota katsellessaan sekä tietokonepelejä pelatessaan. Englanniksi lukeminen ja kirjoittaminen olivat ymmärrettävästi harvinaista. Noin 15 prosenttia 1.-luokkalaisista ilmoitti puhuvansa englantia vähintään kerran viikossa tai jopa päivittäin. Tämä voi liittyä siihen, että varhaisessa kieltenopetuksessa jotkut opettajat antavat oppilaille kotitehtäväksi käyttää kotona englanninkielisiä tervehdyksiä, kysyä vanhemmilta kysymyksiä englanniksi tai laulaa opittuja englanninkielisiä lauluja (ks. Huhta \& Leontjev 2019).

2.-luokkalaisten käyttivät englantia hyvin samalla tavalla kuin 1.-luokkalaiset, mutta käytön määrä kasvoi selvästi. Esimerkiksi englanninkielisten laulujen kuuntelu sekä englanniksi puhuminen ja kirjoittaminen olivat selvästi yleisempää kuin 1.-luokkalaisilla.

3.-luokkalaisilla englannin käyttö päivittäin tai vähintään viikoittain oli selvästi yleisempää kuin 1.- ja 2.-luokkalaisilla. Esimerkiksi englanninkielisten laulujen kuunteleminen sekä tietokonepelien pelaaminen oli päivittäistä tai lähes päivittäistä yli puolella kolmasluokkalaisista. Samoin englanninkielisten tv-ohjelmien katselu oli päivittäistä yli 40 prosentilla 3.-luokkalaisista. Toisin kuin nuoremmilla oppilailla, valtaosa 3.-luokkalaisista kertoi kirjoittavansa jotakin englanniksi vähintään viikoittain. Tämä voi johtua ainakin osittain siitä, että oppilaat ovat ottaneet arvioinnissaan huomioon kotitehtävien tekemisen.

Taulukko 3 esittää vapaa-ajan kielenkäyttöä koskevien kysymysten keskiarvot ja -hajonnat sekä vuosiluokittain tehdyn vertailun tulokset. Analyysejä varten vastaukset koodattiin asteikolle 0-3 (harvemmin tai en koskaan - joka päivä tai melkein joka päivä). Manova-analyysi osoitti, että oppilaiden vuosiluokka vaikutti vastauksiin selvästi (Wilksin Lambda =,656; $F=24,821 ; p<, 001$; efektikoko =,190). Kokonaisuutena tarkastellen oppilaiden vuosiluokka selitti 19 prosenttia vastausten vaihtelusta. 
TAULUKKO 3. Oppilaiden englannin käyttö vapaa-ajalla (vastausvaihtoehdot välillä 0-3). Ka = keskiarvo.

\begin{tabular}{|l|l|l|l|l|l|l|l|l|l|}
\hline $\begin{array}{l}\text { Englannin } \\
\text { käyttötilanne }\end{array}$ & \multicolumn{2}{|l|}{$\begin{array}{l}\text { 1. luokka } \\
\mathrm{N}=145\end{array}$} & \multicolumn{2}{l|}{$\begin{array}{l}\text { 2. luokka } \\
\mathrm{N}=259\end{array}$} & \multicolumn{2}{l|}{$\begin{array}{l}\text { 3. luokka } \\
\mathrm{N}=239\end{array}$} & $\mathrm{~F}$ & $\begin{array}{l}\text { Tilast. } \\
\text { merk. }\end{array}$ & $\begin{array}{l}\text { Efekti- } \\
\text { koko }\end{array}$ \\
\hline & ka. & keskih. & ka. & keskih. & ka. & keskih. & & & \\
\hline $\begin{array}{l}\text { puhuminen } \\
\text { jonkun kanssa }\end{array}$ & 0,46 & 1,007 & 1,04 & 1,106 & 1,59 & 1,166 & 48,16 & $<, 001$ &, 131 \\
\hline laulujen kuuntelu & 1,40 & 1,277 & 1,91 & 1,098 & 2,19 & 1,035 & 22,67 & $<, 001$ &, 066 \\
\hline television katselu & 1,24 & 1,249 & 1,38 & 1,244 & 1,87 & 1,186 & 15,16 & $<, 001$ &, 045 \\
\hline $\begin{array}{l}\text { tietokonepelien } \\
\text { pelaaminen }\end{array}$ & 1,25 & 1,245 & 1,42 & 1,277 & 1,98 & 1,158 & 20,23 & $<, 001$ &, 059 \\
\hline $\begin{array}{l}\text { lukeminen } \\
\text { (lehdet, kirjat) }\end{array}$ & 0,19 &, 577 & 0,44 &, 826 & 1,00 & 1,031 & 45,98 & $<, 001$ &, 126 \\
\hline kirjoittaminen & 0,19 &, 531 & 0,79 &, 962 & 1,73 & 1,011 & 142,25 & $<, 001$ &, 308 \\
\hline
\end{tabular}

Taulukossa 3 esitetyt tarkemmat analyysit osoittavat, että englannin käyttö kasvaa merkitsevästi vuosiluokan mukaan jokaisessa oppilailta kysytyissä tilanteissa. Merkitsevyys tarkistettiin näissäkin Kruskall-Wallisin ei-parametrisella analyysillä. Oppilaat eroavat selvästi toisistaan käytön tiheydessä, mitä suuret keskihajonnat osoittavat: monessa tapauksessa keskihajonta on yhtä suuri jollei isompikin kuin vastausten keskiarvo.

Selvin muutos tapahtuu kirjoittamisessa: vain harvat 1.-luokkalaiset kertoivat kirjoittavansa jotain englanniksi, kun taas 3.-luokkalaisten keskiarvo $(1,73)$ lähestyi vaihtoehtoa 2 eli 1-2 kertaa viikossa. Lähes 31 prosenttia kirjoittamista koskevan kysymyksen vaihtelusta selittyi oppilaiden vuosiluokalla. Selvää kasvua tapahtui myös puhumisessa ja lukemisessa, joissa noin 13 prosenttia vaihtelusta selittyi vuosiluokalla. Muissa tilanteissa (englanninkielisten laulujen kuuntelu, tv-ohjelmien katselu, tietokonepelien pelaaminen) tapahtui myös kasvua, mutta niissä erot vuosiluokkien välillä selittivät vain 5-7 prosenttia vaihtelusta. Yksilökohtainen vaihtelu oli täten kaikissa tapauksissa suurempaa kuin vuosiluokkaan liittyvä vaihtelu, mutta joissakin tapauksissa myös vuosiluokka (oppilaan ikä) vaikutti selvästi siihen, miten usein englantia käytettiin.

Vuosiluokittain tehdyt parittaiset vertailut Games-Howell-menetelmällä osoittivat, että useimmat erot vuosiluokittaisissa keskiarvoissa olivat tilastollisesti merkitseviä, useimmiten tasolla $\mathrm{p}<, 001$. Ainoat tilastollisesti ei-merkitsevät erot löytyivät tv-ohjelmien katselussa ja tietokonepelien pelaamisessa, joissa ensimmäisen ja toisen luokan oppilaat eivät eronneet toisistaan. 


\subsection{Sanastotehtävä}

Lähes kaikki tutkimukseen osallistuneet oppilaat vastasivat ainakin osittain sanastotehtävän helpompaan versioon. Tehtäviä tehdessään oppilaita kannustettiin tekemään parhaansa ja halutessaan arvaamaan, mutta he saivat myös jättää tehtävän kesken niin halutessaan.

1.-luokkalaiset osasivat keskimäärin 28 prosenttia ensimmäisestä sanastotehtävästä, johon oli valikoitu sanoja englannin 500 yleisimmän sisältösanan joukosta. Sen sijaan 2.-luokkalaiset osasivat jo 44 prosenttia ja 3.-luokkalaiset 71 prosenttia sanoista (ks. taulukko 4). 2.- ja 3.-luokkalaiset suorittivat myös toisen, hiukan vaativamman sanastotehtävän, joka perustui 500-1000 yleisimpään sanaan. Vaativamman tehtävän tulokset olivat luonnollisesti keskimäärin matalampia kuin sanastotehtävän ensimmäisessä osassa. 2.-luokkalaiset osasivat keskimäärin 34 prosenttia sanastotehtävän sanoista (keskihajonta 24,5\%), kun taas 3.-luokkalaiset osasivat 59 prosenttia sanoista (keskihajonta 23,86 \%). Näin iso ero suorituksissa oli luonnollisesti myös tilastollisesti merkitsevä $(t=12,114 ;$ p. $<, 001$; Cohenin d-efektikoko = $1,046)$.

\subsection{Segmentointitehtävät suomeksi ja englanniksi}

Suomenkielisen segmentointitehtävän suoritusajat olivat odotuksenmukaisia - kolmasluokkalaiset olivat nopeimpia. Sen sijaan 1.- ja 2.-luokkalaisten suoritusajat eivät erityisesti eronneet toisistaan. Suoritusten keskiarvot ja keskihajonnat on esitetty taulukossa 4. 
TAULUKKO 4. Oppilaiden englannin ja suomen kielen osaaminen: sanastotehtävä ja segmentointitehtävät (englanti ja suomi). Ka = keskiarvo.

\begin{tabular}{|l|l|l|l|l|l|l|l|l|l|}
\hline Tehtävä & \multicolumn{2}{l}{$\begin{array}{l}1 . \text { luokka } \\
\mathrm{N}=136\end{array}$} & \multicolumn{2}{l}{$\begin{array}{l}\text { 2. luokka } \\
\mathrm{N}=290\end{array}$} & \multicolumn{2}{l}{$\begin{array}{l}\text { 3. luokka } \\
\mathrm{N}=274\end{array}$} & $\mathrm{~F}$ & $\begin{array}{l}\text { Tilast. } \\
\text { merk. }\end{array}$ & $\begin{array}{l}\text { Efekti- } \\
\text { koko }\end{array}$ \\
\hline & ka. & keskih. & ka. & keskih. & ka. & keskih & & & \\
\hline $\begin{array}{l}\text { Sanasto } \\
(0-500), \\
(\%)\end{array}$ & 26,76 & 21,015 & 44,36 & 22,430 & 71,31 & 17,849 & 245,366 & $<, 001$ &, 413 \\
\hline $\begin{array}{l}\text { englanti } \\
\text { segment. } \\
\text { (aika (s)) }\end{array}$ & 148,27 & 104,026 & 176,26 & 94,002 & 157,62 & 60,183 & 6,143 &, 002 &, 017 \\
\hline $\begin{array}{l}\text { englanti } \\
\text { segment. } \\
\text { (virheiden } \\
\text { määrä) }\end{array}$ & 51,73 & 12,257 & 41,07 & 18,302 & 19,84 & 14,099 & 227,248 & $<, 001$ &, 395 \\
\hline $\begin{array}{l}\text { suomi } \\
\text { segment. } \\
\text { (aika (s)) }\end{array}$ & 253,18 & 135,562 & 247,67 & 122,419 & 195,64 & 93,136 & 18,417 & $<, 001$ &, 050 \\
\hline $\begin{array}{l}\text { suomi } \\
\text { segment. } \\
\text { (virheiden } \\
\text { määrä) }\end{array}$ & 25,13 & 14,309 & 13,53 & 9,753 & 8,34 & 6,479 & 134,265 & $<, 001$ &, 278 \\
\hline
\end{tabular}

Englanninkielisen segmentointitehtävän suoritusajat sen sijaan näyttävät erikoisilta, sillä 1.-luokkalaiset olivat siinä nopeimpia. Todennäköisesti tehtävä oli 1.-luokkalaisille vielä sen verran haastava, että osa oppilasta jätti tehtävän kesken, mikä näkyy nopeampana suoritusaikana. 2.- ja 3.-luokkalaisten tulokset mukailevat suomenkielisen segmentointitehtävän tuloksia: 3.-luokkalaiset olivat keskimäärin 2.-luokkalaisia nopeampia. Suoritusten keskiarvot ja keskihajonnat on esitetty taulukossa 4. Taulukko 4 esittää myös vuosiluokittain tehdyn vertailun tulokset. Manova-analyysi osoitti, että oppilaiden vuosiluokka vaikutti vastauksiin selvästi (Wilksin Lambda = ,460; $F=65,705 ; \mathrm{p}<, 001$; efektikoko =,322). Kokonaisuutena tarkastellen oppilaiden vuosiluokka selitti 32 prosenttia vaihtelusta heidän englannin ja suomen osaamisessaan.

Oppilaiden suoritustarkkuus molemmissa segmentointitehtävässä parani vuosiluokan mukaan: 3.-luokkalaiset olivat tarkimpia. Sen sijaan 1.- ja 2.-luokkalaisten merkitsemien väärien tai ylimääräisten sanarajojen määrässä ei ollut suurta eroa (ks. taulukko 4). Koska moni 1.-luokkalainen jätti tehtävän kesken, jäi virheiden määrä luonnollisesti pienemmäksi. Muutoin segmentointitehtävien tarkkuutta koskevat tulokset olivat odotuksenmukaisia: mitä ylemmällä luokalla oppilas oli - eli mitä vahvempi oppilaiden luku- ja kirjoitustaito yleensä oli - sitä paremmin oppilas näissä tehtävissä menestyi (ks. taulukko 4). 
Tehtäväkohtaiset analyysit osoittavat, että selkeimmät erot vuosiluokkien välillä tutkimuksessa tarkastelluilla kielitaidon osa-alueilla olivat englannin sanaston laajuudessa: helpomman sanastotestin vaihtelusta peräti 41 prosenttia selittyi oppilaiden vuosiluokalla. Lähes yhtä isot erot vuosiluokkien välillä löytyivät englanninkielisen segmentointitehtävän suoritustarkkuudessa (melkein 40 \%). Myös suomenkielisessä segmentointitehtävässä suoritustarkkuus erotteli vuosiluokkia melko selkeästi: noin 28 prosenttia eroista selittyi vuosiluokalla.

Segmentointitehtävän suoritusaika ei sen sijaan eronnut eri vuosiluokkien oppilailla kovinkaan paljon, vaikkakin silti tilastollisesti merkitsevästi. Suoritusnopeus on ilmeisesti varsin henkilökohtainen ominaisuus: suomenkielisen segmentoinnin eroista vuosiluokka selitti vain 5 prosenttia ja englanninkielisen eroista vajaat 2 prosenttia. Ei-parametriset analyysit vastasivat jälleen varianssianalyysien tuloksia, eli kaikissa tehtävissä eri vuosiluokkien oppilaiden osaaminen erosi merkitsevästi.

Vuosiluokittain tehdyissä parittaisissa vertailuissa englannin sanastotestin ja molempien segmentointitehtävien suoritustarkkuudet erosivat kaikkien vuosiluokkien välillä merkitsevästi $(p<, 001)$. Suomenkielisen segmentointitehtävän suoritusajassa 1.- ja 2.-luokkalaiset eivät eronneet toisistaan, mutta 3.-luokkalaiset olivat muita merkitsevästi nopeampia. Englanninkielisen segmentointitehtävän suoritusajassa 1.- ja 2.-luokkalaiset erosivat toisistaan, samoin kuin 2.- ja 3.-luokkalaiset, mutta 1.- ja 3.-luokkalaiset puolestaan eivät. Tämä johtunee siitä, että 1.-luokkalaiset juoksivat tehtävän läpi sen haastavuuden vuoksi.

\section{Pohdinta}

Tutkimuksemme tulokset osoittavat, että englannin opiskeluun ja englannin kieleen suhtaudutaan myönteisesti aloitusiästä riippumatta. Kolmasluokkalaiset pärjäsivät parhaiten englannin kielitaitoa mittaavissa tehtävissä, he arvioivat osaamisensa korkeammaksi kuin 1.- ja 2.-luokkalaiset ja he käyttivät eniten englantia vapaa-ajallaan. Erot olivat tilastollisesti merkitseviä. Tulosten tarkempi tarkastelu osoitti lähes kaikissa osioissa suuren keskihajonnan, mikä viittaa suureen yksilökohtaiseen vaihteluun. Tulokset ovat linjassa aiempien tutkimusten kanssa niin asenteiden kuin kielitaidon näkökulmasta (Muñoz 2006; Enever 2011; Myles \& Mitchell 2012; Jäkel ym. 2017).

Tulokset kuitenkin osoittavat myös, että varhaisella kieltenopetuksella voidaan kasvattaa oppilaiden kielitaitoa ja luoda positiivista suhtautumista kieltenopiskeluun vähintään hetkellisesti. Tarkasteltaessa 1.- ja 2.-luokkalaisten motivaatiota opiskella englantia huomataan tulosten toistavan aiempien tutkimusten (Myles 2017; Cenoz 2003; Enever 2011) havaintoja nuorten lasten innokkuudesta opiskella kieliä. Lisäksi huomataan, että vaikka 1.-luokkalaiset arvioivat osaamisensa heikommaksi kuin 2.- ja 3.-luokkalaiset, heistä noin viidesosa arvioi kuitenkin osaavansa 
englantia jo aika hyvin (vrt. Brumen 2011). Toki on myös huomattava, että tehtävässä käytetty arviointiasteikko oli hyvin karkea ja laadukas itsearviointi yleisestikin vaatii harjoittelua.

Vaikka oppilaiden tekemät itsearvioinnit ovat vain suuntaa antavia, ne auttavat ymmärtämään mahdollisia eroja esimerkiksi eri vuosiluokkien sanastonhallinnassa. 3.-luokkalaisten englannin sanavarasto oli selvästi laajempi kuin 1.- ja 2.-luokkalaisten, vaikka jokaisella ryhmällä oli sama määrä opintoja takanaan. Huolimatta 1.- ja 2.-luokkalaisten heikommista tuloksista valtaosa oppilaista kaikilla vuosiluokilla katsoi sekä puhumis- että ymmärtämistaitojensa parantuneen puolen vuoden opiskelun aikana. Jatkossa olisi hyvä seurata, miten erityisesti 1. ja 2. luokalla kieltenopiskelun aloittaneiden oppilaiden motivaatio ja suhtautuminen kieltenopiskeluun kehittyy vuosien saatossa ja kokevatko he myöhemmillä vuosiluokilla samanlaista turhautumista kuin on todettu aikaisemmissa tutkimuksissa (Pfenninger \& Singleton 2016a, 2016b).

Tuloksista käy myös ilmi, että englannin käyttö vapaa-ajalla lisääntyy selvästi oppilaan vuosiluokan ja iän myötä ja että nuorimpien oppilaiden vapaa-ajan käyttö on melko vähäistä (vrt. Unsworth ym. 2014; Dahl \& Vulchanova 2014; Muñoz ym. 2018). Erityisen suuri harppaus englannin kielen käytössä tapahtuu toisen ja kolmannen luokan välillä: monessa eri vapaa-ajan harrastuksessa 3.-luokkalaisten raportoima englannin lähes päivittäinen käyttö on kymmeniä prosenttiyksikköjä korkeampaa kuin 2.-luokkalaisten vastaava käyttö. Toki voi myös olla, että vanhemmat oppilaat tiedostivat paremmin, millä tavoin ja miten usein he käyttävät englantia vapaa-ajallaan.

Tutkimuksemme myös osoitti, että mitä vanhempi oppilas oli kyseessä, sitä enemmän hän englannin kielestä piti ja sitä paremmaksi hän osaamisensa arvioi. Aikaisempi tutkimus on osoittanut, että kohdekielen runsas käyttö vapaa-ajalla voi johtaa kokemukseen oman osaamisen puutteellisuudesta (Sundqvist \& Sylvén 2014). Oma tutkimuksemme ei osoita samaa, sillä 3.-luokkalaiset sekä käyttivät englantia eniten vapaa-ajallaan että arvioivat osaamisensa parhaimmaksi.

Oppilaiden kohdekielen käyttö vapaa-ajalla ja toisaalta suhtautuminen kohdekieleen muodostavat joka tapauksessa mielenkiintoisen ja monimutkaisen suhteen - voisi kuvitella, että mahdollisuudet hyödyntää kohdekieltä omassa arjessa kasvattaisivat oppilaan motivaatiota opiskella kieltä koulussa. Näin voisi tulkita myös oman tutkimuksemme tuloksia. Toisaalta, kun tuloksiamme verrataan Sundqvistin ja Sylvénin (2014) tutkimukseen, saadaan pontta uudelle kysymykselle. Heidän tutkimuksessaan oppilaat olivat vain yhden vuosiluokan ylemmällä luokalla. Voisiko siis 3. ja 4. luokan välissä tapahtua niin runsas määrällinen kasvu englannin kielen käytössä vapaa-ajalla, että myös kielitaidon puutteellisuuden huomaaminen olisi todennäköisempää, jolloin myös motivaatio ja arvio omasta osaamisesta heikkenisi? Joka tapauksessa on selvää, että kognitiivisen kyvykkyyden kehittyminen, kielitaito, 
motivaatio ja tietoisuus englannin käytöstä vapaa-ajalla muodostavat hyvin monitasoisen vyyhdin.

3.-luokkalaisten menestyksekkäämmälle suoriutumiselle voi nimetä monia syitä. Kuten aiemmissa tutkimuksissa on todettu (Hannibal Jensen 2017), kohdekielen käyttö vapaa-ajalla tukee koulussa hankitun kielitaidon kehittymistä. Toisaalta 3.-luokkalaisilla on luonnollisesti myös vahvempi äidinkielen hallinta - mikä osaltaan näkyi myös suomenkielisessä segmentointitehtävässä - kuin myös kokemusta kielitehtävistä ja kokeista. Todennäköisesti myös oppilaiden ikä, kypsyystaso ja yleinen kognitiivinen kyvykkyys ovat vaikuttaneet kielitehtävien tuloksiin, kuten aiemmissa tutkimuksissa on todettu (Muñoz 2006; Cenoz 2009).

Koesuoriutumiseen ovat voineet vaikuttaa myös erot opetustavoissa ja -materiaaleissa. 1.- ja 2.-luokkalaisten opetus on pääsääntöisesti painottunut kuullun ymmärtämiseen ja suullisen kielitaidon kehittämiseen (Inha 2018), jolloin harjaantuminen kirjalliseen kieleen on voinut olla hyvin vähäistä jollei täysin olematonta. Aiempien tutkimusten perusteella erilainen lähestymistapa kieleen ja kielenopiskeluun voi vaikuttaa siihen, minkälaisia tuloksia ja mitä osaamista erilaisilla mittaustavoilla saadaan näkyväksi (Cenoz 2009) ja toisaalta miten oppilaat ylipäätänsä suhtautuvat kieltenopiskeluun ja omaan osaamiseensa (Mihaljević Djigunović 2009). Siten tuloksissa esille tuotu osaaminen on myös johdannainen mittaustavasta.

\section{Lopuksi}

Keväällä 2018 kerätty aineisto ja sen tulokset antavat poikkileikkauskuvan kieltenopiskelun alkuaskeleista. Esittelemämme tulokset myötäilevät aiempien tutkimusten löydöksiä, mutta vasta pidemmän aikavälin tutkimus antaa niistä selkeämmän kuvan. Aineisto onkin kerätty siitä lähtökohdasta, että se tarjoaisi lupaavan pohjan pitkittäistutkimukselle. Jatkossa seuraamme tutkimuksessa mukana olleiden oppilaiden osaamisen ja motivaation kehittymistä heidän edetessään vuosiluokalta toiselle. Pyrimme arvioimaan englannin - mahdollisesti myös äidinkielen - kehittymistä laajemmin kuin vuonna 2018, esimerkiksi mittaamalla erityisesti suullista vuorovaikutusta, tekstin ymmärtämistä ja kirjoittamista. Tässä tutkimuksessa oppilaiden kielitaitoa lähestyttiin oletuksesta, että opintojen alussa opetetaan kaikkein yleisimpiä sanoja ja rakenteita, sekä valitsemalla sellaisia aikaisemmissa tutkimuksissa validoituja tehtäviä, jotka mittaavat tällaista osaamista. Jatkossa olisi hyvä käyttää tehtäviä, joissa kielenkäyttötaito tulisi laajemmin esille, hyödyntää uusia perusteita (Opetushallitus 2019) sekä mahdollisesti myös kartoittaa, mitä aihepiirejä varhainen kieltenopetus tyypillisesti sisältää. Näin mittauksissa saataisiin paremmin esiin erityisesti 1.-luokkalaisille kertynyt osaaminen.

Jatkossa tutkimuksen olisi tärkeä tarkastella varhaista kieltenopetusta myös laajemman kielikasvatuksen näkökulmasta. Vuoden 2014 perusteet edellyttävät ai- 
empaa selvemmin käsittämään kieltenopetuksen laajemmin kuin vain oppilaiden kielitaidon kehittämisenä. Toukokuussa 2019 julkaistujen perusteiden mukaisesti varhaisen kieltenopetuksen tulee kannustaa oppilasta rohkeaksi kielenkäyttäjäksi sekä tukea hänen kasvuaan kulttuuriseen moninaisuuteen ja kielitietoisuuteen. Tässä artikkelissa referoitujen tutkimuksien mukaan varhaisen kieltenopetuksen vaikutus kielitaitoon on verrattain vähäinen. Sen sijaan on vielä epäselvää, toteutuvatko varhaisen kieltenopetuksen vaikutukset pikemminkin työkaluina, joita lapsi tarvitsee kasvaessaan kielellisesti ja kulttuurisesti yhä moninaisempaan maailmaan.

\section{Kirjallisuus}

Alderson, J. C., E.-L. Haapakangas, A. Huhta, L. Nieminen \& R. Ullakonoja 2015. The diagnosis of reading in a second or foreign language. Lontoo: Routledge.

Alderson, J. C., A. Huhta \& L. Nieminen 2016. Characteristics of weak and strong readers in a foreign language. The Modern Language Journal, 100 (4), 853-879. https://doi. org/10.1111/modl.12367.

Becker, C. \& J. Roos 2016. An approach to creative speaking activities in the young learners' classroom. Education Inquiry, 7 (1), 9-26. https://doi.org/10.3402/edui.v7.27613.

British Council Peru \& Norwich Institute for Language Education (NILE) 2017. English teaching in the early years: research in Peru. Report. April-September 2017. Lima: British Council. www.britishcouncil.pe/sites/default/files/informe_nile_english.pdf.

Brumen, M. 2011. The perception of and motivation for foreign language learning in preschool. Early child development and care, 181 (6), 717-732. https://doi.org/10.1080/03 004430.2010 .485313$.

Böttger, H. \& N. Schlüter 2019. Englischunterricht in der Grundschule doch effektivGegendarstellung zur Untersuchung von Jäkel/Ritter. https://www.researchgate.net/ publication/331703008_Englischunterricht_in_der_Grundschule_doch_effektiv_-_ Gegendarstellung_zur_Untersuchung_von_JakelRitter [luettu 20.5.2019].

Cenoz, J. 2003. Teaching English as a third language: the effect of attitudes and motivation. Teoksessa C. Hoffmann \& J. Ytsma (toim.) Trilingualism in family, school and community. Clevedon: Multilingual Matters, 202-218.

Cenoz, J. 2009. The age factor in bilingual and multilingual education. Teoksessa J. Cenoz (toim.) Towards multilingual education: Basque educational research from an international perspective. Bristol: Multilingual Matters, 189-212.

Dahl, A. \& M. D. Vulchanova 2014. Naturalistic acquisition in an early language classroom. Frontier in Psychology, 5, 1-9. https://doi.org/10.3389/fpsyg.2014.00329.

$\mathrm{ECML}=$ European Centre for Modern Languages ECML 2019a. European portfolio for preprimary educators. The plurilingual and intercultural dimension. https://www.ecml.at/ ECML-Programme/Programme2012-2015/Pepelino/tabid/1833/language/en-GB/ Default.aspx [luettu 27.5.2019].

$\mathrm{ECML}=$ European Centre for Modern Languages ECML 2019b. Inspiring language learning in the early years. Why it matters and what it looks like for children age 3-12. https://www.ecml.at/ECML-Programme/Programme2016-2019/ Inspiringlanguagelearningandteachingintheearlyyears/tabid/3015/language/en-GB/ Default.aspx [luettu 27.5.2019].

Edelenbos, P., R. Johnstone \& A. Kubanek 2006. The main pedagogical principles underlying 
the teaching of languages to very young learners. Languages for the children of Europe: Published Research, Good Practice \& Main Principles. Final Report of the EAC 89/04, Lot 1 study. Bryssel: Euroopan komissio. http://ec.europa.eu/assets/eac/languages/policy/ language-policy/documents/young_en.pdf.

Enever, J. (toim.) 2011. ELLiE: Early language learning in Europe. Lontoo: British Council. https://www.teachingenglish.org.uk/sites/teacheng/files/B309\%20ELLiE\%20 Book\%202011\%20FINAL.pdf.

Engel, G. \& B. Groot-Wilken 2007. English in primary schools in North Rhine-Westphalia (NRW). Teoksessa G. Engel, B. Trimbos, I. Drew \& B. Groot-Wilken (toim.) CIDREE Report: English in primary education in the Netherlands, North-Rhine Westphalia (NRW) and Norway. http://www.cidree.org/wp-content/uploads/2018/07/report_ engel_e.a.pdf.

Euroopan komissio 2003. Promoting language learning and linguistic diversity: an action plan 2004-2006. Bryssel: Euroopan komissio. https://eur-lex.europa.eu/ LexUriServ/LexUriServ.do?uri=COM:2003:0449:FIN:EN:PDF.

Euroopan komissio 2011. Language learning at pre-primary school level: making it efficient and sustainable - a policy handbook. Bryssel: Euroopan komissio. https://ec.europa. eu/education/content/commission-staff-working-paper-language-learning-preprimary-level-making-it-efficient-and_en.

Euroopan komissio/EACEA/Eurydice 2017. Key data on teaching languages at school in Europe - 2017 Edition. Eurydice report. Luxemburg: Publications Office of the European Union. https://doi.org/10.2797/839825.

Euroopan neuvosto 2007. Guide for the development of language education policies in Europe. Strasbourg: Euroopan neuvosto. https://m.coe.int/ CoERMPublicCommonSearchServices/ DisplayDCTMContent?documentld $=09000016802 \mathrm{fc} 1 \mathrm{c} 4$.

Euroopan neuvosto 2015. The language dimension in all subjects: a handbook for curriculum development and teacher training. Strasbourg: Euroopan neuvosto. https://www.ecml. at/coe-docs/language-dimensions-subjects-EN.pdf.

Euroopan unionin neuvosto 1998. Neuvoston päätöslauselma. Euroopan yhteisöjen virallinen lehti 3.1.1998. https://eur-lex.europa.eu/legal-content/FI/TXT/ PDF/?uri=CELEX:31998Y0103(01)\&from=EN [luettu 16.5.2019].

García Mayo, M. P. 2003. Age, length of exposure and grammaticality judgements in the acquisition of English as a foreign language. Teoksessa M. P. García Mayo \& M. L. García Lecumberri (toim.) Age and the acquisition of English as a foreign language. Clevedon: Multilingual Matters, 94-114.

Graham, S., L. Courtney, T. Marinis \& A. Tonkyn 2017. Early language learning: the impact of teaching and teacher factors. Language Learning, 67 (4), 922-958. https://doi. org/10.1111/lang.12251.

Hannibal Jensen, S. H. 2017. Gaming as an English language learning resource among young children in Denmark. CALICO Journal, 34 (1), 1-19. https://doi.org/10.1558/cj.29519.

Holopainen, L., L. Kairaluoma, J. Nevala, T. Ahonen \& M. Aro 2004. Lukivaikeuksien seulontamenetelmä nuorilla ja aikuisille. Jyväskylä: Niilo Mäki Instituutti.

Huhta, A. \& D. Leontjev 2019. Kieltenopetuksen varhentamisen kärkihankkeen seurantapilotti. Loppuraportti. Jyväskylä: Soveltavan kielentutkimuksen keskus. https://www. jyu.fi/hytk/fi/laitokset/solki/tutkimus/julkaisut/pdf-julkaisut/kieltenopetuksenvarhentamisen-karkihankkeen-seurantapilotti-loppuraportti.pdf.

Inha, K. 2018. Vuosi kärkihanketta takana. Kieli, koulutus ja yhteiskunta, 9 (4). https://www. 
kieliverkosto.fi/fi/journals/kieli-koulutus-ja-yhteiskunta-kesakuu-2018/vuosikarkihanketta-takana.

Jyväskylän yliopisto 2014. DIALUKI: Toisen tai vieraan kielen lukemisen ja kirjoittamisen diagnosointi. https://www.jyu.fi/hytk/fi/laitokset/solki/tutkimus/projektit/dialuki/su [luettu 26.8.2019].

Jäkel, N., M. Schurig, M. Florian \& M. Ritter 2017. From early starters to late finishers? A longitudinal study of early foreign language learning in school. Language Learning 67 (3), 631-664. https://doi.org/10.1111/lang.12242.

DeKeyser, R. M. 2013. Age effects in second language learning: stepping stones toward better understanding. Language Learning, 63 (suppl. 1), 52-67. https://doi. org/10.1111/j.1467-9922.2012.00737.x.

Mattila, P. 2015. Kielikasvatus eurooppalaisena tehtävänä. Teoksessa A-K. Mustaparta (toim.) Kieli koulun ytimessä - näkökulmia kielikasvatukseen. Helsinki: Opetushallitus. http://www.oph.fi/download/176255_kieli_koulun_ytimessa_nakokulmia_ kielikasvatukseen.pdf.

Mihaljević Djigunović, J. 2009. Impact of learning condition on young FL learners's motivation. Teoksessa M. Nikolov (toim.) Early learning of modern foreign languages: processes and outcomes. Bristol: Multilingual Matters, 75-89.

Mitchell, R. \& F. Myles 2018. Learning French in the UK setting: policy, classroom engagement and attainable learning outcomes. Apples: Journal of Applied Language Studies, 13 (1), 69-93. http://apples.jyu.fi/article/abstract/586.

Muñoz, C. 2006. The effects of age on foreign language learning. Teoksessa C. Muñoz (toim.) Age and the rate of foreign language learning. Clevedon: Multilingual Matters, 1-40.

Muñoz, C. 2008. Symmetries and asymmetries of age effects in naturalistic and instructed L2 learning. Applied Linguistics, 29 (4), 578-596. https://doi.org/10.1093/applin/amm056.

Muñoz, C., T. Cadierno \& I. Casas 2018. Different starting points for English language learning: a comparative study of Danish and Spanish young learners. Language Learning, 68 (4), 1076-1109. https://doi.org/10.1111/lang.12309.

Mustaparta, A-K., L. Nissilä \& M. Harmanen 2015. Kielikasvatus - yhteinen tehtävä. Teoksessa A-K. Mustaparta (toim.) Kieli koulun ytimessä - näkökulmia kielikasvatukseen. Helsinki: Opetushallitus. http://www.oph.fi/download/176255_kieli_koulun_ytimessa_ nakokulmia_kielikasvatukseen.pdf.

Myles, F. \& R. Mitchell 2012. Learning French from ages 5,7, and 11: an investigation into starting ages, rates and routes of learning amongst early foreign language learners. ESRC End of Award Report, RES-062-23-1545. Swindon: ESRC. http://www.ripl.uk/wpcontent/uploads/2017/03/EOA-Report-RES-062-23-1545.pdf.

Myles, F. 2017. Learning foreign languages in primary schools: is younger better? http://www. meits.org/policy-papers/category/florence-myles [luettu 2.2.2019].

Nikolov, M. \& J. Mihaljević Djigunović 2011. All shades of every color: an overview of early teaching and learning of foreign languages. Annual Review of Applied Linguistics, 31 (1), 95-119. https://doi.org/10.1017/S0267190511000183.

Opetushallitus 2014. Perusopetuksen opetussuunnitelman perusteet 2014. Helsinki: Opetushallitus. http://www.oph.fi/download/163777_perusopetuksen_ opetussuunnitelman_perusteet_2014.pdf.

Opetushallitus 2019a. Kieltenopetuksen kehittäminen. https://www.oph.fi/fi/koulutus-jatutkinnot/kieltenopetuksen-kehittaminen [luettu 13.5.2019].

Opetushallitus 2019b. Perusopetuksen opetussuunnitelman perusteiden 2014 muutokset ja täydennykset koskien A1-kielen opetusta vuosiluokilla 1-2. Helsinki: Opetushallitus. https://beta.oph.fi/fi/tilastot-ja-julkaisut/julkaisut/perusopetuksenopetussuunnitelman-perusteiden-2014-muutokset-ja. 
Opetus- ja kulttuuriministeriö 2018. Ehdotus perusopetuslaissa tarkoitetun opetuksen valtakunnallisista tavoitteista ja tuntijaosta annetun asetuksen sekä perusopetusasetuksen muuttamisesta. Muistio. https://valtioneuvosto.fi/delegate/ file/45556 [luettu 9.2.2019].

Pfenninger S. E. \& D. Singleton 2016a. Affect trumps age: a person-in-context relational view of age and motivation in SLA. Second Language Research, 32 (3), 311-345. https://doi. org/10.1177/0267658315624476.

Pfenninger S. E. \& D. Singleton 2016b. The age factor in the foreign language class: what do learners think? Theory and Practice of Second Language Acquisition, 2 (1), 7-23. http:// www.journals.us.edu.pl/index.php/TAPSLA/article/view/3930.

Piske, T. 2017. The earlier, the better? Teoksessa E. Wilden \& R. Porsch (toim.) The professional development of primary EFL teachers. National and international research. Münster: Waxmann, 45-57.

Schmitt, N., D. Schmitt \& C. Clapham 2001. Developing and exploring the behavior of two versions of the vocabulary levels test. Language Testing, 18 (1), 55-88. https://doi.org/ $10.1177 / 026553220101800103$.

Skinnari, K. \& A. Halvari 2018. Varhennettua kieltenopetusta vai kaksikielistä toimintaa? Varhaisen kieltenopetuksen puurot ja vellit. Kieli, koulutus ja yhteiskunta, 9 (4). https://www.kieliverkosto.fi/fi/journals/kieli-koulutus-ja-yhteiskuntakesakuu-2018/varhennettua-kieltenopetusta-vai-kaksikielista-toimintaa-varhaisenkieltenopetuksen-puurot-ja-vellit.

Sundqvist, P. \& L. K. Sylvén 2014. Language-related computer use: focus on young L2 English learners in Sweden. ReCALL, 26 (1), 3-20. https://doi.org/10.1017/ S0958344013000232.

Tellier, A. J. \& R. Myles 2018. Learning French from ages 5, 7 and 11. Summary. http://www.ripl. uk/wp-content/uploads/2018/03/MylesSummaryFinal.pdf [luettu 20.5.2019].

Unsworth, S., L. Persson, L. Prins \& K. de Bot 2014. An investigation of factors affecting early foreign language learning in the Netherlands. Applied Linguistics, 38 (5), 1-24. https:// doi.org/10.1093/applin/amt052.

Valtioneuvoston asetus perusopetuksen valtakunnallisista tavoitteista ja tuntijaosta (422/2012). https://www.finlex.fi/fi/laki/ alkup/2012/20120422?search\%5Btype\%5D=pika\&search\%5Bpika\%5D=422\%2F2012 [luettu 2.2.2019].

Valtioneuvoston asetus perusopetuslaissa tarkoitetun opetuksen valtakunnallisista tavoitteista ja perusopetuksen tuntijaosta annetun valtioneuvoston asetuksen 6 §:n muuttamisesta (793/2018). https://www.finlex.fi/fi/laki/alkup/2018/20180793 [luettu 11.2.2019].

Vipunen 2019. Kieli-ja muut ainevalinnat. https://vipunen.fi/fi-fi/esi-ja-perusopetus [luettu 27.5.2019].

Wilden, E., R. Porsch \& J. Ehmke 2017. TEPS - Teaching English in primary schools. https:// www.researchgate.net/project/TEPS-Teaching-English-in-Primary-Schools [luettu 20.5.2019]. 